\title{
The Relationship between Educational Resources of School and Academic Achievement
}

\author{
Havva Sebile SAVASCI $^{1} \&$ Ekber TOMUL ${ }^{2}$ \\ ${ }^{1}$ Isaabat Primary School, Provincial Directorate of National Education, Tutak, Agrı, Turkey \\ ${ }^{2}$ Faculty of Education, Mehmet Akif Ersoy University, 15100-Burdur, Turkey \\ Correspondence: Ekber TOMUL, Faculty of Education, Mehmet Akif Ersoy University, 15100-Burdur, Turkey. \\ Tel: 90-248-213-4047. E-mail: etomul@mehetakif.edu.tr; ekbertomul@gmail.com
}

\author{
Received: March 4, 2013 Accepted: March 8, $2013 \quad$ Online Published: March 13, 2013 \\ doi:10.5539/ies.v6n4p114 URL: http://dx.doi.org/10.5539/ies.v6n4p114
}

\begin{abstract}
The educational resources of schools play an important role in order to diminish the effect of socioeconomic features on academic achievement, and create equal opportunities for students. In this sense, it is highly crucial to investigate the relationship between the educational resources of schools and the academic achievement of students. This study aims to determine the relationship between the academic achievement level of 7 th grade students and the educational resources of schools. The population of the study was the elementary schools in the province of Burdur in 2007-2008 academic years. Two-stage cluster sampling was conducted in conformity with the aim of the study. First, settlements were chosen with geographical cluster sampling. As settlement, city centers, town centers, small towns and villages were considered in the study.

Considering the relationship between the educational resources of the schools and the academic achievement as a whole, there are negative and significant relationships between the SBS scores of the students, and the average service length of the teachers, the lack of qualified science teachers, the lack of qualified Turkish teachers, the lack of the teachers in other courses and the lack of the laboratory technicians. It can be said that there is a relationship between the educational resources and academic achievement. However, this relationship is fairly limited. It is still not possible to say that the educational resources do not have the strength to diminish the effect of the socioeconomic features.
\end{abstract}

Keywords: inequality, educational resources, academic achievement, equal opportunities

\section{Introducation}

It is endorsed that academic achievement of students is related to individual differences between students, socioeconomic features in which they grow up, and educational resources of students' current school. The relationship between socioeconomic features and academic achievement has been extensively studied within national and international context in recent years (Tomul \& Savasci, 2012). However, there is a dearth of the studies about the relationship between educational resources of school and academic achievement. Educational resources are of vital importance in terms of its role in attaining educational aims and objectives. In this sense, educational resources play a significant role in order to provide equal opportunities for students by diminishing the effect of socioeconomic factors on academic achievement. The level of attaining educational aims and objectives is directly related to educational resources and use of them.

The role of schools in academic achievement has been investigated in many countries since the equality of educational opportunity report in the year of 1966 in USA (Rivkin, Hanushek \& Kain, 2005). There are, in fact, different results for the studies that investigate the relationship between educational resources of schools and academic achievement. Some studies indicate that educational resources of schools do not have an effect on academic achievement of students (Hanushek, 1997; Hanushek \& Luque, 2003; Hakkinen et al., 2003). On the other hand, some studies say the exact opposite (Card \& Krueger, 1996; Greenwald, Hedges \& Laine, 1996).

Card and Krueger (1996), Greenwald and et al. (1996), Fuller and Clarke (1994), and Heyneman and Loxley (1983) recognize the effect of physical and economic resources on achievement. Physical resources can be categorized under the headings of people, equipment, physical and economic resources. According to the analysis of Ferreira and Gignoux (2010) based on the data of PISA 2006, family and school conditions account 
for at least $26 \%$ of Turkish and mathematics scores and $27 \%$ of science scores of students. In Demir's (2009) study, variables about school only accounts for $4.3 \%$ of variance.

There are some studies which indicate that the effect of educational resources on student achievement depends on the development level of a country, as well. To account for academic achievement of students, factors related to school is more effective in developing countries, and social background of students is more effective in developed countries (Fuller \& Clarke, 1994; Heyneman \& Loxley, 1983). Adeogun and Osifila (2008) found that there are positive relationships between academic achievement of students and physical, financial and material resources. However, human resources are found not to be significantly related to students' academic performance. In PISA (Ministry of National Education, 2003) report, it is shown that the lack of physical resources has a negative effect on students, and it hinders learning of students. In developing countries, the relationship between student achievement, and student-teacher ratio, education level of teachers and school facilities is more apparent than in developed countries. Nevertheless, it is not right to mention about a strong relationship within this context (Wößmann, 2003; Hanushek, 2006). Furthermore, developing countries trail developed countries in terms of educational resources such as student-teacher ratio, teachers' level of education and school facilities. As a consequence, developing countries trail developed countries in terms of academic achievement on an international scale (Glewwe \& Kremer, 2006). Considering these results, Wößmann (2003) suggests that educational resources have a diminishing effect on academic achievement. According to the study of Hanushek $(1986,1997)$ on the relationship between student-teacher ratio, education level of teachers and school facilities, and student achievement, there is a poor relation between educational resources and student achievement.

Somers (2001) reported positive effects of student-teacher ratio, educational materials, library size, and teacher education on learning outputs. For effective learning, some studies in low-income countries emphasize the significance of human and financial resources that include subconstruction of schools, classroom size, teacher experiences, teacher abilities, and educational materials (Fuller \& Clarke, 1994; Heyneman \& Loxley, 1983). Demir (2009) touched upon the effect of student-teacher ratio on academic achievement, and suggested student-teacher ratio is the most significant predictive of academic achievement. However, physical and financial potential of schools is found not to have a significant effect on achievement.

According to the ideas of school managers in the countries where PISA studies are carried out, physical difficulties related to subconstruction have little restrictive effect on the instruction capacity of schools. In Greece, Mexico, Poland, Turkey, Brazil, Lithuania, Indonesia, Serbia, Thailand, Tunisia, Uruguay and Russian Federation, the school managers mention that lack of teaching aids or its poor quality hinder instruction quality (Ministry of National Education, 2003). In the study of PISA (Ministry of National Education, 2003), over two third of the school managers think that learning of the students below the age of 15 is prevented due to the lack of the quality in physical subconstruction. The number of the school managers who thinks that the lack of physical subconstruction has many negative effects on learning is about to reach to the half of the total population. In PISA (Ministry of National Education, 2003), 80\% of the school managers think that learning of the students below the age of 15 is prevented to some extent due to the lack of the quality in educational resources. Approximately half of the school managers think that the lack of quality in educational resources of schools prevents student learning to a "great" extent. In PISA (Ministry of National Education, 2003), around three fourth of the school managers detect "insufficiency in the number of teachers in schools" as another factor having an effect on student learning. Around half of the school managers consider insufficiency in the number of teachers in schools as a serious problem.

In Turkey, there are different school types, and this differentiation is parallel with socioeconomic and cultural situation to a great extent (Education Reform Initiative, 2009). It is possible to evaluate the partial development in PISA scores as a result of education expenditures that has gained momentum recently (Ozenc \& Arslanhan, 2010). When the educational expenditures are analyzed in Turkey, it seems that these expenditures are prone to increase inequality. $37 \%$ of the educational expenditures were provided by private sector (private establishments and household). Another reason for why the amount of private expenditures in total educational expenditures creates problems is the huge differentiation in the amount of expenditures among income groups. The expenditures of the wealthiest $20 \%$ are over 21 times what the poorest $20 \%$ spend for educational expenditures (Education Reform Initiative, 2009). When student-teacher ratio and student-classroom ratio are considered, İstanbul and Southestearn Region of Anotalia fall behind other regions, and these regions should be given priority within this context (Education Reform Initiative, 2009).

The effect of urban districts is undeniable in all education levels. Tansel (1998) pinpoints that the effect of urban districts is of importance in all education levels except female students in primary schools, and adds that (1) 
effect coefficient is greater for female students than the male students, (2) dwelling in undeveloped districts is not important in primary school level; however, it has a negative effect for both female and male students in secondary schools, (3) dwelling in disadvantageous districts diminishes school skills, and this effect is higher for female students than male students. Ferreira and Gignoux (2010), who analyze PISA 2006 results, focus on the statistically significant relationship between the schools in Eastern regions or rural districts and low test scores of students. According to this study, spatial variables, at most, might account for one fifth of the inequal opportunity regarding quantitative success level of education sector in Turkey.

The literature manifests that there is a relationship between student number and achievement, and achievement is higher for the classrooms having less students than the classrooms having more students. In some ways, uncrowded classrooms make it easier for teachers, as well. There is not an ideal classroom size since it depends on the nature of lessons, education level and type (Rivkin, Hanushek \& Kain, 2005; Lindahl, 2005; Krueger, 1999; Ehrenberg, Brewer, Gamoran \& Willms, 2001). According to Guclu (2002), the amount of the allocated time decreases for individual instruction in large classrooms. However, the results do not corroborate with this study in terms of the effect of the classroom size on student achievement. Lindahl (2005) reported that some small and economically embarred groups benefit from small-size classrooms in Sweden. Moreover, Wößmann (2003) concluded from the study which was applied in the year of 1994-1995 academic years in 39 participating countries that student achievement in the field of Mathematics and Science is related to the size of the classroom to a great extent. The findings of Lindahl support the findings of Angrist and Lavy (1999), and Krueger (1999). On the other hand, these findings are in contradiction with the findings of Hoxby's study (2000) which indicates that the size of the classroom does not have a significant effect on academic achievement.

Additionally, some studies point to the effect of teacher qualifications on academic achievement. According to Rivkin, Hanushek and Kain's study (2005), the professional experiences of teachers have a significant effect on mathematic achievement of students. To be more precise, the experience year of teachers has a significant effect on mathematic achievement when they are compared to fresh teachers who have 1 to 3 years. On student achievement, attitudes and behaviors of teachers are other criteria to think over. The values, attitudes and experiences of teachers affect students, societies, their careers and colleagues, and, naturally, teachers form their personal and professional existence by being affected the same factors (Sama \& Tarim, 2007). As Darling-Hammond and Sykes defined, the significant qualifications of teachers are verbal ability, knowledge in the field, knowledge about how to teach and learn, and the ability to use teaching strategies based on the needs of students. In this sense, Demir (2009) found that the education level of teachers, length of service, and participated in-service trainings have a significant effect on the academic achievement of students. On the other hand, some studies state that length of service is not a good predictive of learning outcomes for teachers (Goldhaber \& Brewer, 1996; Rivkin et al., 2005). To sum up, the educational resources of schools play an important role in order to diminish the effect of socioeconomic features on academic achievement, and create equal opportunities for students. In this sense, it is highly crucial to investigate the relationship between the educational resources of schools and the academic achievement of students.

This study aims to determine the relationship between the academic achievement level of 7 th grade students and the educational resources of schools.

\section{Method}

The population of the study was the elementary schools in the province of Burdur in 2007-2008 academic years. The views of elementary school managers were taken regarding the relationship between the educational sources of schools and academic achievement. As a mean of academic achievement, the scores of the students who firstly sat placement test named as SBS in 2007-2008 academic years were taken into consideration. The one of the components is SBS to pass high school. In Turkey, the students are placed into high schools with their high school placement test scores based on score superiority and preferences. High school pass system is a student-centered model established on two structures as placement test (SBS) and year-end achievement score. SBS is a central standardized test which is organized each year in June, and it aims to determine to what extent students learn the objectives of $6^{\text {th }}, 7^{\text {th }}$ and $8^{\text {th }}$ grades' curriculum. It was first applied to $7^{\text {th }}$ graders in 2007 academic year. SBS is not a compulsory examination. However, students are suggested to take this test since it has an effect on the score which is used to place students into high schools that admit students with the central placement. The important feature of these tests is that it is related to learning objectives, and the number of the questions is determined according to weekly course hours. In SBS, there are questions from Turkish, Mathematics, Science and Technology, Social Sciences, Foreign Language, Education of Religions and Ethics. 
According to the settlement in the province of Burdur, the numbers of the elementary schools in 2007-2009 academic years and the distribution of the $7^{\text {th }}$ grade students in these schools were given in Table 1.

Table 1. The distribution of 7 th grade students in Burdur

\begin{tabular}{llllll}
\hline $\begin{array}{l}\text { The Settlement Area of The } \\
\text { Schools }\end{array}$ & $\begin{array}{l}\text { The } \\
\text { number of } \\
\text { the schools }\end{array}$ & Male & Female & Overall & $\begin{array}{l}\text { The numbers of the } \\
\text { students took SBS } \\
\text { exam }\end{array}$ \\
\hline City Centers & 24 & 499 & 496 & 995 & 938 \\
Town Centers & 32 & 828 & 748 & 1576 & 1502 \\
Small Towns and Villages & 49 & 454 & 454 & 908 & 696 \\
Overall & 105 & 1781 & 1698 & 3479 & 3136 \\
\hline
\end{tabular}

According to Table 1, 28.60\% (995) of 7th grade students study at the schools in city centers, $45.30 \%(1576)$ at the schools in town centers, $26.10 \%(908)$ at the schools in villages. The percentages of male and female students are $51.19 \%$ (1781) and $48.81 \%$ (1698) respectively.

Two-stage cluster sampling was conducted in conformity with the aim of the study. First, settlements were chosen with geographical cluster sampling. Secondly, the schools were chosen randomly in selected settlement (Geray, 2006). As settlement, city centers, town centers, small towns and villages were considered in the study.

The data about the schools chosen as the sampling were given in Table 1. According to Table 2, the data were collected from 19 schools (802 students) in the city center of Burdur, 13 schools (923 students) in town center, 9 schools (269 students) in small towns and villages.

Table 2. The distribution of the numbers of the schools and the students in the sampling group

\begin{tabular}{lcccc}
\hline \multicolumn{1}{c}{ The settlement area which } & The number of the & \multicolumn{3}{c}{ The number of the students } \\
\cline { 2 - 5 } schools are located & schools & Male & Female & Overall \\
\hline City Centers & 19 & 410 & 392 & 802 \\
Town Centers & 13 & 477 & 446 & 923 \\
Small Towns and Villages & 9 & 142 & 127 & 269 \\
Overall & & 1029 & 965 & 1994 \\
\hline
\end{tabular}

\subsection{Data Collection Instruments}

In order to collect the data, the institutional information questionnaires were used. The school questionnaire is formed by making use of the 2006 report of the Programme for International Student Assessment (PISA) of the Organisation for Economic Co-operation and Development (OECD). For reliability and validity, the opinions of experts and school managers were considered. In the institutional information questionnaire, there was some information about the school. Furthermore, some items were included about educational resources hindering academic achievement regarding the views of the school administration. The questionnaire was conducted to the state schools by the researcher.

\subsection{Data Analysis}

To analyze the data, statistical techniques such as arithmetic mean, standard deviation, percentage and frequency distribution were used. Spearman's correlation coefficient was used to determine the correlation between variables. The significancy level was considered as $\mathrm{p}<0.05$.

\section{Results}

For the schools, the distribution of sources of income was given in Table 3 regarding their settlement. Considering the results in Table 3, the sources of the schools were the student fees, and the fees paid by families $(53.41 \%)$. The contribution of the government was just on the level of $15.61 \&$. The incomes obtained from the grants were on the level of $25.32 \%$. According to the settlement, a great extent of the school incomes was provided by the student fees or families ( $48.89 \%$ in villages, $49.58 \%$ in towns, 57.75 in cities). The contribution of the government to the schools was $5.56 \%$ for the schools in villages, $14.58 \%$ for the schools in the towns, and $18.10 \%$ for the schools in the city. These results indicated that the facilities of the schools in villages, towns and 
cities depend on the socioeconomic situation of the students. In the villages, towns and cities, the facilities of the schools are directly related to the socioeconomic levels of the students. In other words, the higher socioeconomic level students have, the more facilities their schools obtain.

Table 3. The distribution of income sources of the schools regarding their settlement (\%)

\begin{tabular}{lllll}
\hline & Village & Town & City & Total \\
\hline Government contribution & 5.56 & 14.58 & 18.1 & 15.61 \\
Student Fees or the Fees Paid by Families & 48.89 & 49.58 & 57.75 & 53.41 \\
$\begin{array}{l}\text { Benefactors, Grants, Wills, Financial Provider, The Money Gained } \\
\text { from Families }\end{array}$ & 43.34 & 21.67 & 19.4 & 25.32 \\
Others & 2.22 & 14.17 & 2.1 & 5.66 \\
\hline
\end{tabular}

The distribution of classroom sizes was given in Table 4 regarding the settlement of the schools. Table 4 indicates that the average classroom size is lower in villages $(\bar{X}: 23)$, and higher in town centers $(\bar{X}: 26)$. The teachers work mostly at the schools in the town centers, and they work minimum length at the schools in the villages. In this sense, the length of service depends on the settlement of the schools. Furthermore, the teachers in the village schools give less service $(\bar{X}: 2.1)$ in the same village schools than the teachers give service in the town schools $(\bar{X}: 3.1)$. These results can be interpreted as that the teachers of the village schools work in inconvenient environments, and, in turn, they change their schools. The long length of service in the town centers results from the occupancy rate of the schools in city centers.

Table 4. The average classroom sizes, the service length of the teachers, and the service length of teachers in the same school regarding the settlement of the schools

\begin{tabular}{ccccc}
\hline $\begin{array}{c}\text { The Settlement } \\
\begin{array}{c}\text { Area of the } \\
\text { Schools }\end{array}\end{array}$ & $\mathrm{n}$ & $\begin{array}{c}\text { The average } \\
\text { classroom sizes }\end{array}$ & $\begin{array}{c}\text { The service length of the } \\
\text { teachers in the same settlement } \\
\text { (Year) }\end{array}$ & $\begin{array}{c}\text { The service length of the } \\
\text { teachers in the same school } \\
\text { (Year) }\end{array}$ \\
\hline City Center & 19 & 24 & 8.7 & 2.9 \\
Town Center & 13 & 26 & 9.6 & 3.1 \\
Village & 9 & 23 & 6.3 & 2.1 \\
\hline
\end{tabular}

Regarding the problems about the physical sources and the number of employees, the views of the school managers were given in Table 5. According to Table 5, "the lack of other support staff" is the most effective factor $(\bar{X}: 2.49)$ which gives rise to the problems about the teaching capacity of the schools. "The lack of softwares or the insufficiency of softwares" has the least effect on the teaching capacity $(\bar{X}: 1.76)$. Regarding the settlement of the schools, "the lack of qualified mathematics teachers" is the most effective factor for education capacity in city centers $(\bar{X}: 2.55)$. The least effective factor is "the lack of internet connection" ( $\bar{X}: 1.35)$. "The lack of other support staff" is the most effective factor for education capacity in town centers ( $\bar{X}: 2.33)$. "The lack of the boks and materials in libraries" has the least effect on the education capacity ( $\bar{X}$ : 1.67). In villages, the factor having an effect on the education capacity is "the lack of qualified teachers in other courses" ( $\bar{X}: 3.00)$. The effect of "the lack of teaching materials" on education capacity is very low $(\bar{X}: 1.78)$. These results indicate that (I) there is lack of teachers in some courses, (II) the schools need the support staffs in the schools and the courses, and (III) there exists enough teaching materials, books and computer softwares about teaching. 
Table 5. The views of the school managers regarding the problems about the physical sources and the number of the employees

\begin{tabular}{lccccccccccccc}
\hline & \multicolumn{1}{c}{ City Center } & \multicolumn{1}{c}{ Town Center } & \multicolumn{4}{c}{ Village } & \multicolumn{4}{c}{ Overall } \\
\hline & $\mathrm{n}$ & $\bar{X}$ & $\mathrm{~S}$ & $\mathrm{n}$ & $\bar{X}$ & $\mathrm{~S}$ & $\mathrm{n}$ & $\bar{X}$ & $\mathrm{~S}$ & $\mathrm{n}$ & $\bar{X}$ & $\mathrm{~S}$ \\
& 19 & 2.15 & 1.23 & 13 & 1.92 & 1.24 & 9 & 2.56 & 1.24 & 41 & 2.17 & 1.22 \\
The Lack of Qualified Science Teachers & 19 & 2.55 & 1.32 & 13 & 1.92 & 1.24 & 9 & 2.78 & 1.48 & 41 & 2.41 & 1.34 \\
The Lack of Qualified Mathematics Teachers & 19 & 1.95 & 1.10 & 13 & 1.75 & 1.06 & 9 & 2.44 & 1.33 & 41 & 2.00 & 1.14 \\
The Lack of Qualified Turkish Teachers & 19 & 2.20 & 1.06 & 13 & 1.75 & 0.97 & 9 & 3.00 & 1.00 & 41 & 2.24 & 1.09 \\
The Lack of Qualified Teachers in Other Courses & 19 & 19 & 2.40 & 1.39 & 13 & 2.25 & 1.06 & 9 & 2.89 & 1.45 & 41 & 2.46 & 1.31 \\
The Lack of Laboratory Technicians & 19 & 2.40 & 1.10 & 13 & 2.33 & 0.98 & 9 & 2.89 & 1.05 & 41 & 2.49 & 1.05 \\
The Lack of Other Support Staffs & 19 & 2.00 & 0.97 & 13 & 2.25 & 1.06 & 9 & 2.33 & 1.22 & 41 & 2.15 & 1.04 \\
The Lack of Science Laboratory Equipments & 19 & 1.80 & 1.06 & 13 & 1.75 & 1.14 & 9 & 1.78 & 1.30 & 41 & 1.78 & 1.11 \\
The Lack of Teaching Materials & 19 & 1.75 & 1.02 & 13 & 1.92 & 1.08 & 9 & 2.00 & 0.87 & 41 & 1.85 & 0.99 \\
The Lack of Computers Reserved for Teaching & 19 & 1.35 & 0.49 & 13 & 2.00 & 1.13 & 9 & 2.67 & 1.12 & 41 & 1.83 & 1.00 \\
The Lack of Internet Connection & 19 & 1.50 & 0.69 & 13 & 1.75 & 0.97 & 9 & 2.33 & 1.22 & 41 & 1.76 & 0.94 \\
The Lack of Educational Softwares & 19 & 1.65 & 0.81 & 13 & 1.67 & 0.98 & 9 & 2.22 & 1.09 & 41 & 1.78 & 0.94 \\
The Lack of Books or Materials in Libraries & 19 & 2.00 & 0.97 & 13 & 1.83 & 1.03 & 9 & 2.56 & 1.01 & 41 & 2.07 & 1.01 \\
The Lack of Visual Auditory Materials & & & & & & & & & & &
\end{tabular}

When Table 6 is analyzed, the mean score of 7th grade students was 327.03, and the mean score of the classrooms was 345.39. Considering the settlement, the mean SBS scores were 354.14, 283.03 and 293.54 for city centers, town centers and villages respectively. These mean scores indicate that the mean scores of the students in town centers are higher than the students in city centers and villages. The lowest SBS mean score is at village schools. Accordingly, the students in town centers are more successful. The classroom mean scores of the students in town centers are higher than the classroom mean scores of the students in the city centers and the villages.

Table 6. The mean SBS scores of 7th grade students regarding the settlement

\begin{tabular}{llllllllllllll}
\hline & \multicolumn{3}{c}{ Overall } & \multicolumn{4}{c}{ City Center } & \multicolumn{3}{c}{ Town Center } & \multicolumn{3}{c}{ Village } \\
\hline & $\mathrm{n}$ & $\bar{X}$ & $\mathrm{~S}$ & $\mathrm{n}$ & $\bar{X}$ & $\mathrm{~S}$ & $\mathrm{n}$ & $\bar{X}$ & $\mathrm{~S}$ & $\mathrm{n}$ & $\bar{X}$ & $\mathrm{~S}$ \\
SBS Score & 41 & 327.03 & 42.60 & 19 & 354.14 & 43.12 & 13 & 383.03 & 35.86 & 9 & 293.54 & 31.08 \\
\hline
\end{tabular}

In Table 7, the relationship between the educational sources of the schools and academic achievement was presented regarding the settlement. In Table 7, the relationship between the educational sources of the schools and academic achievement was analyzed. It was found that there are negative and significant correlations between the SBS scores of the students, and the average service length of the teachers, the lack of qualified science teachers, the lack of qualified Turkish teachers, the lack of qualified teachers in other courses and the lack of laboratory technicians. Regarding the settlement, in city centers, positive correlations were found between the academic achievement of the students and the average service length of the teachers, and negative correlations were found between the academic achievement of the students, and the lack of laboratory technicians and the average classroom size. In town centers, there are negative significant correlations between the academic achievement of the students and the government resources. In villages, there are negative correlations between the academic achievement of the students and the financial contributions of the students, and positive correlations between the academic achievement of the students and the grants. 
Table 7. The relationship between the educational sources of the schools and academic achievement regarding the settlement

\begin{tabular}{|c|c|c|c|c|c|}
\hline & & $\begin{array}{l}\text { City } \\
(\mathrm{n}: 19)\end{array}$ & $\begin{array}{l}\text { Town } \\
\text { (n:13) }\end{array}$ & $\begin{array}{l}\text { Village } \\
(\mathrm{n}: 9)\end{array}$ & $\begin{array}{r}\text { Overall } \\
\text { (n: 41) }\end{array}$ \\
\hline \multirow{2}{*}{ Government Resources } & Corr. Coeff. & -0.04 & -0.79 & 0.44 & -0.04 \\
\hline & $\mathrm{p}$ & 0.87 & 0.00 & 0.24 & 0.81 \\
\hline \multirow{2}{*}{ Student Fees } & Corr. Coeff. & 0.13 & 0.30 & -0.75 & 0.08 \\
\hline & $\mathrm{p}$ & 0.57 & 0.35 & 0.02 & 0.63 \\
\hline \multirow{2}{*}{ Grants } & Corr. Coeff. & 0.16 & -0.31 & 0.74 & -0.09 \\
\hline & $\mathrm{p}$ & 0.49 & 0.32 & 0.02 & 0.58 \\
\hline \multirow{2}{*}{ Others } & Corr. Coeff. & 0.13 & -0.14 & 0.10 & 0.07 \\
\hline & $\mathrm{p}$ & 0.57 & 0.66 & 0.79 & 0.65 \\
\hline \multirow{2}{*}{ The average service length } & Corr. Coeff. & 0.50 & -0.32 & -0.01 & -0.44 \\
\hline & $\mathrm{p}$ & 0.03 & 0.31 & 0.98 & 0.00 \\
\hline \multirow{2}{*}{ The Lack of Qualified Science Teachers } & Corr. Coeff. & -0.28 & -0.27 & -0.32 & -0.31 \\
\hline & $\mathrm{p}$ & 0.23 & 0.40 & 0.40 & 0.05 \\
\hline \multirow{2}{*}{ The Lack of Qualified Mathematics Teachers } & Corr. Coeff. & -0.27 & 0.05 & -0.26 & -0.23 \\
\hline & $\mathrm{p}$ & 0.25 & 0.87 & 0.50 & 0.15 \\
\hline \multirow{2}{*}{ The Lack of Qualified Turkish Teachers } & Corr. Coeff. & -0.40 & -0.21 & -0.20 & -0.33 \\
\hline & $\mathrm{p}$ & 0.08 & 0.51 & 0.61 & 0.03 \\
\hline \multirow{2}{*}{ The Lack of Qualified Teachers in Other Courses } & Corr. Coeff. & -0.28 & -0.03 & -0.31 & -0.34 \\
\hline & $\mathrm{p}$ & 0.23 & 0.92 & 0.42 & 0.03 \\
\hline \multirow{2}{*}{ The Lack of Laboratory Technicians } & Corr. Coeff. & -0.66 & -0.15 & 0.35 & -0.43 \\
\hline & $\mathrm{p}$ & 0.00 & 0.63 & 0.35 & 0.00 \\
\hline \multirow{2}{*}{ The Lack of Other Support Staffs } & Corr. Coeff. & -0.32 & 0.13 & -0.26 & -0.23 \\
\hline & $\mathrm{p}$ & 0.16 & 0.68 & 0.50 & 0.14 \\
\hline \multirow{2}{*}{ The Lack of Science Laboratory Equipments } & Corr. Coeff. & -0.23 & 0.11 & -0.13 & -0.12 \\
\hline & $\mathrm{p}$ & 0.33 & 0.73 & 0.74 & 0.47 \\
\hline \multirow{2}{*}{ The Lack of Teaching Materials } & Corr. Coeff. & 0.11 & -0.08 & 0.24 & 0.11 \\
\hline & $\mathrm{p}$ & 0.65 & 0.81 & 0.54 & 0.51 \\
\hline \multirow{2}{*}{ The Lack of Computers Reserved for Teaching } & Corr. Coeff. & -0.21 & -0.31 & 0.16 & -0.19 \\
\hline & $\mathrm{p}$ & 0.38 & 0.32 & 0.68 & 0.23 \\
\hline \multirow{2}{*}{ The Lack of Internet Connection } & Corr. Coeff. & 0.00 & 0.10 & -0.16 & -0.13 \\
\hline & $\mathrm{p}$ & 1.00 & 0.75 & 0.68 & 0.41 \\
\hline \multirow{2}{*}{ The Lack of Educational Softwares } & Corr. Coeff. & 0.01 & -0.27 & -0.37 & -0.21 \\
\hline & $\mathrm{p}$ & 0.97 & 0.40 & 0.33 & 0.18 \\
\hline \multirow{2}{*}{ The Lack of Books or Materials in Libraries } & Corr. Coeff. & -0.16 & 0.03 & 0.02 & -0.16 \\
\hline & $\mathrm{p}$ & 0.50 & 0.92 & 0.96 & 0.31 \\
\hline \multirow{2}{*}{ The Lack of Visual Auditory Materials } & Corr. Coeff. & -0.17 & -0.41 & 0.20 & -0.31 \\
\hline & $\mathrm{p}$ & 0.47 & 0.18 & 0.60 & 0.05 \\
\hline \multirow{2}{*}{ The average classroom size } & Corr. Coeff. & -0.59 & -0.03 & -0.65 & -0.30 \\
\hline & $\mathrm{p}$ & 0.01 & 0.94 & 0.06 & 0.06 \\
\hline
\end{tabular}




\section{Discussion}

Considering the educational resources of the school, a large amount of the school incomes is obtained by the student fees or the family contributions. In terms of the settlement, the educational resources of the schools were obtained by the student fees or the contributions of the families in city centers, town centers and villages, as well. Thus, it can be suggested that the educational resources of the schools are directly related to the socioeconomic situation of the families, and the higher socioeconomic level students have, the more facilities their schools obtain.

When it comes to the mean classroom sizes of the schools, the classrooms in the villages are less crowded, and the classrooms in town centers are more crowded. In terms of length of service in the same school, the teachers in the village schools give less service in the same village schools than the teachers give service in the town schools. In the village schools, since the teachers change their schools, and the opportunities in the village schools are limited, the SBS scores of the students are low.

In this study, the classroom sizes are less in the village schools; however, their academic achievement is also low. This result indicates that the classroom size does not have an effect on the academic achievement, and it corroborates with the studies of Hoxby (2008) and Demir (2009) which concluded that the classroom size does not have an effect on the academic achievement. On the other hand, these results are in conflict with the studies of Uludag and Odaci (2002), Guclu (2002), Yaman (2006), Wöbmann (2003), Lindahl (2005), Angrist and Lavy (1999), Krueger (1999), Rivkin, Hanushek and Kain, (2005), Ehrenberg, Brewer, Gamoran and Willms, (2001). They found that the less the number of the students are in a classroom, the higher academic achievement students have.

According to the school managers, there is no relationship between the academic achievement and the lack of teachers. However, this idea conflicts with the findings of the international studies. While the low student-teacher ratio has more effect on the test results, it mitigates its effect in high levels (Borland et al, 2005; Hanushek, 2006).

"The lack of other support staff" is the most impediment factor in the teaching capacity. The least impediment factor is "the lack of educational softwares". Regarding the teaching capacity in terms of the settlement, the most impediment factor is "the lack of qualified Mathematics teachers" in city centers. The least impediment factor is "the lack of internet connection" in city centers. For the schools in town centers, the most impediment factor is "the lack of other support staff", and the least impediment factor is "the lack of books or materials in libraries". In the villages, the most impediment factor is "the lack of the teachers in other courses", and the least impediment factor is "the lack of teaching materials".

Considering the relationship between the educational resources of the schools and the academic achievement as a whole, there are negative and significant relationships between the SBS scores of the students, and the average service length of the teachers, the lack of qualified science teachers, the lack of qualified Turkish teachers, the lack of the teachers in other courses and the lack of the laboratory technicians. It can be said that there is a relationship between the educational resources and academic achievement. However, this relationship is fairly limited. It is still not possible to say that the educational resources do not have the strength to diminish the effect of the socioeconomic features.

To sum up, the educational resources of the schools are not at a level which can affect the academic achievement of the students. These results corroborate with the remarks of Hanushek (2006) which is "it is a common result in the literature that the educational resources are not statistically effective". The effect of the socioeconomic factors on the student achievement remains at the forefront.

\section{Acknowledgement}

This study was carried out with the some data of master's dissertation called as "The Relationship between the Academic Achievement of 7th Grade Students, and Socioeconomic Variables and Educational Resources of Schools" which was prepared by Havva Sebile SAVAŞÇI with thesis advisor Assoc. Prof. Dr. Ekber TOMUL in Social Sciences Institution of Mehmet Akif Ersoy University.

\section{References}

Adeogun, A. A., \& Osifila, G. I. (2008). Relationship between educational resources and students' academic performance in Lagos State Nigeria. International Journal of Educational Management, 5-6, 144-153. 
Angrist, J. D., \& Lavy, V. (1999). Using Maimonides' rule to estimate the effect of class size on scholastic achievement. The Quarterly Journal of Economics, 114, 533-575. http://dx.doi.org/10.1162/003355399556061

Card, D., \& Krueger, A. (1996). School resources and student outcomes: An overview of the literature and new evidence from North and South Carolina. Journal of Economic Perspectives, 10, 31-40. http://dx.doi.org/10.1257/jep.10.4.31

Darling-Hammond, L., \& Sykes, G. (2003). Wanted: A national teacher supply policy for education: the right way to meet the 'Highly Qualified Teacher' challenge. Educational Policy Analysis Archives, 11, 33-50.

Demir, C. E. (2009). Factors influencing the academic achievement of the Turkish urban poor. International Journal of Educational Development, 29, 17-29. http://dx.doi.org/10.1016/j.ijedudev.2008.03.003

Dincer, M. A., \& Uysal Kolasin, G. (2009). The determinants of the inequality in the student achievement of Turkey. Education Reform Initiative, Sabancı University.

Education Reform Initiative. (2009). Equality in education, policy analysis and recommendations. İstanbul: Education Reform Initiative Report. Sabanci University publications.

Ehrenberg, R. G., Brewer, D. J., Gamoran, A., \& Willms, J. D. (2001). Class size and student achievement. Psychological Science in the Public Interest, 2(1), 1-30. http://dx.doi.org/10.1111/1529-1006.003

Ferreira, F. H. G., \& Gignoux, J. (2010). Inequality of opportunity for education: The case of Turkey. State Planning Organization of the Republic of Turkey and World Bank. Working Paper Number: 4.

Fuller, B., \& Clarke, P. (1994). Raising school effects while ignoring culture? Local conditions and the influence of classroom tools, rules and pedagogy. Review of Educational Research, 64, 122-131.

Geray, H. (2006). Introduction to qualitative and quantitative methods in social research (2th ed.). Ankara: Siyasal kitapevi.

Glewwe, P., \& Kremer, M. (2006). Schools, teachers, and educational outcomes in developing countries. In Eric A. Hanushek, \& Finis, Welch (Eds.), Handbook of the Economics of Education. Amsterdam: North Holland: 943-1017.

Goldhaber, D. D., \& Brewer, D. J. (1996). Evaluating the effect of teacher degree level on educational performance. Retrieved from http://nces.ed.gov/pubs97/ 975351.pdf

Greenwald, R., Hedges, L.V., \& Laine, R. (1996). The effect of school resources on student achievement. Review of Educational Research, 66, 361-396.

Guclu, M. (2002). Crowded classroom problem in elementary schools and the solutions to this problem. Eurasian Journal of Educational Research, 9, 52-58.

Hakkinen, I., Kirjavainen, T., \& Uusitalo, R. (2003). School resources and student achievement revisited: new evidence from panel data. Economics of Education Review, 22, 329-335. http://dx.doi.org/10.1016/S0272-7757(02)00060-2

Hanushek, E. A., \& Luque, J. A. (2003). Efficiency and equity in schools around the world. Economics of Education Review, 22, 481-502. http://dx.doi.org/10.1016/S0272-7757(03)00038-4

Hanushek, E. A. (1997). Assessing the effects of school resources on student performance: An update. Educational Evaluation and Policy Analysis, 19(2), 141-164.

Hanushek, E. A., Rivkin, S. G., \& Taylor, L. L. (1996). Aggregation and the estimated effects of school resources. The Review of Economics and Statistics, 78(4), 611-627. http://dx.doi.org/10.2307/2109949

Heyneman, S. P., \& Loxley, W. A. (1983). The effect of primary school quality on academic achievement across 29 high- and low-income countries. American Journal of Sociology, 88(6), 1162-1194. http://dx.doi.org/10.1086/227799

Hoxby, C. M. (2000). The effects of class size on student achievement: New evidence from population variation. Quarterly Journal of Economics, 115(4), 1239-1285. http://dx.doi.org/10.1162/003355300555060

Krueger, A. (1999). Experimental estimates of education production functions. The Quarterly Journal of Economics, 114, 497-532. http://dx.doi.org/10.1162/003355399556052 
Lindahl, M. (2005). Home versus school learning: A new approach to estimating the effect of class size on $\begin{array}{lllll}\text { achievement. Scandinavian Journal of Economics, } & \text { 107(2), 375-394. }\end{array}$ http://dx.doi.org/10.1111/j.1467-9442.2005.00413.x

Ministry of National Education. (2005). PISA 2003 Project National Final Report. MEB, ANKARA.

Ministry of National Education. (2007). PISA 2006 National Preliminary Report. MEB, ANKARA.

Ozenc, B., \& Arslanhan, S. (2010). An evaluation of PISA 2009 results, TEPAV Evaluation Note

Rivkin, S. G., Hanushek, E. A., \& Kain, J. F. (2005). Teachers, schools and academic achievement. Econometrica, 73(2), 417-458. http://dx.doi.org/10.1111/j.1468-0262.2005.00584.x

Sama, E., \& Tarim, K. (2007). The attitudes and behaviors of the teachers towards the students they perceived as unsuccessful. Journal of Turkish Educational Sciences, 5(1), 135-154.

Tansel, A. (1998). Determinants of school attainment of boys and girls in Turkey. Center Discussion Paper, No: 789.

Tomul, E., \& Savasci, H. S. (2012). Socioeconomic Determinants of Academic Achievement. Educational Assessment, Evaluation and Accountability, 24(3), 175-187. http://dx.doi.org/10.1007/s11092-012-9149-3

Uludag, Z., \& Odaci, H. (2002). The physical environment in education-instruction facilities. National Education Journal, 153-154.

Wößmann, Ludger. (2003). Schooling resources, educational institutions and student performance: The International Evidence. Oxford Bulletin of Economics and Statistics, 65(2), 117-170. http://dx.doi.org/10.1111/1468-0084.00045

Yaman, E. (2006). One of the dimensions in the education system: Large classrooms and classroom management. Journal of Turkish Educational Sciences, 4(3), 261-274. 